\title{
Невідкладна допомога при тяжкій формі міастенії
}

\author{
І.С. Зозуля, А.О. Восоловець \\ Національний університет охорони здоров'я України імені П.Л. Шупика, Київ, Україна
}

Тяжка форма міастенії - рідкісне захворювання, яке відмічають 3 частотою 20 випадків на 100 тис. населення віком $>60$ років. У патогенезі захворювання головну роль відіграє аутоімунний процес з утворенням антитіл у тимусі та лімфатичній системі проти постсинаптичних нікотинергічних ацетилхолінових рецепторів, в результаті чого відбувається блокування рецепторів (особливо в рухових пластинках) до виснаження передачі нейром'язового збудження. Другий механізм - вироблення антитіл до специфічної м'язової тирозинкінази. Антитіла до рецепторів ацетилхоліну виявляють у 70-90\% пацієнтів із міастенією гравіс. Існують також серонегативні пацієнти, у яких наявні типові симптоми міастенії гравіс, проте не виявлені підвищені рівні антитіл. Ця група пацієнтів становить 30\%. У 70\% пацієнтів відмічається гіперплазія тимусу (тимома або карцинома) - паранеопластична тяжка міастенія.

\section{Клінічна картина}

У клінічній картині спостерігають:

- аномальну, пов'язану з фізичним навантаженням, слабкість і втому м'язів (особливо проксимальних відділів кінцівок потилиці, плечей) з підсиленням протягом дня, покращенням після відпочинку;

- двоїння в очах (порушення рухів очей), птоз (з одного або обох боків), що покращується у спокої;

- пов'язані з фізичним напруженням тахіпное та диспное;

- порушення ковтання, жування, мовлення (гнусава мова).

Виокремлюють: 1) очну, око-глотко-лицьову; 2) генералізовану; 3) тяжку гостру генералізовану; 4) генералізовану форму середнього ступеня тяжкості; 5) тяжку хронічну прогресуючу; 6) тяжку генералізовану; 7) тяжку форму міастенії з атрофічними вадами; 8) тяжку форму міастенії, що потребує інтубації.

Окремо виділяють пацієнтів із нестабільними бульбарними або респіраторними симптомами (аспірація або порушення ковтання).

Смертність при міастенічному кризі становить 5-12\%.

Міастенічний криз - загрозливе для життя загострення генералізованої форми міастенії з дихальною недостатністю, тяжким порушенням ковтання, загрозою аспірації і високим ступенем прогресуючої м'язової слабкості.

Провокуючі фактори: інфекції, застосування глюкокортикоїдів (у початковій стадії), емоційний стрес, тяжкі операції, наркоз.

Діагностика міастенічного кризу не становить труднощів.

При клінічній картині в'ялого тетрапарезу, порушенні функції ковтання і респіраторній недостатності диференційна діагностика включає синдром Гійєна - Барре, синдром Ламберта - Ітона, гостру інтермітуючу порфірію, ботулізм, отруєння фосфорорганічними сполуками.

Холінергічний криз має такі самі симптоми, як і міастенічний. Для діагностики необхідно провести тест з едрофонієм. Відсутність реакції вказує на холінергічний криз. Діагностика включає серологічні реакції на антитіла, електрофізіологічне дослідження.

\section{Діагностика}

Прості клінічні тести:

1. Тест Сімпсона: пацієнт дивиться вгору протягом 60 с при міастенічній слабкості птоз збільшується.
2. Тест з кубиками льоду при птозі: пацієнт тримає мішочок із льодом протягом 1-2 хв, закривши очі. Птоз зменшується в результаті інгібування викиду ацетилхоліну.

3. Ознака Когана: птоз зменшується після сильного зажмурювання очей (активація кругового м'яза ока), що приводить до «відпочинку» м'яза і підняття повік.

4. Тести на навантаження з наростанням втоми через 1-2 хв.

5. Тест на втому повік (Сімпсона) - погляд вгору 1 хв.

6. Тест на двоїння в очах при навантаженні (погляд у бік протягом >1 хв).

7. Тест на моргання (відкрити/закрити очі).

8. Стиснення руки в кулак.

9. Витягування рук уперед.

10. Утримання ноги у фіксованому положенні.

11. Утримання голови у фіксованому положенні.

12. Tensilon-тест: внутрішньовенне введення едрофонію хлориду в дозі 10 мг (1 мл 1\% розчину) протягом 10 с. При позитивному результаті вираженість м'язової слабкості зменшується. Можливі побічні ефекти: брадикардія, напад бронхіальної астми, нудота, діарея, збільшення виділення слини і секрету бронхів (допомога - введення 0,5-1 мг атропіну підшкірно).

13. Тест з піридостигміном: через 30-60 хв після введення в дозі 30-60 мг - покращення моторики.

14. Внутрішньовенне введення неостигміну.

Лабораторна діагностика включає визначення антитіл до ацетилхоліну, тирозинкінази. Слід виключити тимому або карциному тимусу. Визначити рівень гормонів щитоподібної залози. Провести електродіагностику лицьового нерва.

Методи візуалізації: комп'ютерна томографія/магнітно-резонансна томографія органів грудної клітки та середостіння, сцинтиграфія (виключити тимому).

Диференційна діагностика:

1. Синдром Ламберта - Ітона (утворення антитіл проти пресинаптичних потенціалзалежних кальцієвих каналів). У клінічній картині: порушення функції тазових органів, імпотенція, гіпотонія, пото- і слиновиділення. Tensilon-тест від'ємний.

2. Ботулізм (враховувати дані анамнезу).

3. Поліміозит, очний міозит, мітохондріальна міопатія (біль у м'язах, підвищення рівня креатинкінази).

4. Око-глоткова м'язова дистрофія (провести біопсію м'язів).

5. Періодичні паралічі.

6. Аміотрофічний латеральний склероз.

7. Розсіяний склероз.

8. Синдром Гійєна - Барре, синдром Міллєра - Фітера.

\section{Лікування}

Загальнотерапевтичні заходи включають.

- моніторинг функції серцево-судинної системи;

- аналіз газового складу крові;

- регулярний контроль життєвої ємності легень, при необхідності - штучна вентиляція легень;

- профілактика тромбозів;

\section{Специфічна терапія}

1. Піридостигмін у формі таблеток з індивідуальним підбором дози до 90 мг кожні 3-4 год, інколи 80-190 мг (депо-форма) на ніч 
або протягом дня через кожні 5-6 год, краще натще, максимальна доза - до 500 мг/добу. Ретардована форма препарату — при нічних або вранішніх виражених симптомах. Застосування у дозі $>600$ мг/добу може призвести до холінергічного кризу.

2. Можливі затяжна прогресуюча м'язова слабкість, внутрішньочеревні спазми, нудота, блювання, діарея, гіперсалівація, бронхорея, потовиділення, м'язові спазми, міоз, збудливість, епілептичні напади. Лікування: атропін, іпратропію бромід (таблетки по 15 мг, максимальна доза 180-300 мг/добу). Дія настає швидко, але коротша, ніж у піридостигміну. Піридостигмін у дозі 30 мг перорально, максимальна доза 25 мг/добу, можна внутрішньовенно через перфузор (25 мг/50 мл, швидкість введення 0,5-1 мг/год).

3. При порушенні ковтання - едрофоній.

4. Глюкокортикоїди: першочергова доза 0,5-1,5 мг/кг маси тіла метилпреднізолону або преднізолону перорально. При досягнені ремісії дозу знижують.

5. Азатіоприн 2-3 мг/кг маси тіла на добу у 2-3 прийоми. Підтримувальна доза 100-150 мг/добу, небажано з алопуринолом.

6. Циклоспорин у початковій дозі 3-5 мг/кг маси тіла, підтримувальна доза - 2 мг (до 5 мг/кг маси тіла у 2 прийоми).

7. Циклофосфамід - резервний препарат при тяжкій міастенії. Перорально 1-2 мг/кг маси тіла або пульс-терапія 500700 мг/кг поверхні тіла кожні 4-12 тиж.

8. Метотрексат 7,5-15 мг 1 раз на тиждень.

9. Імуноглобуліни внутрішньовенно.

10. Плазмаферез, імуносорбція.
11. Тімектомія.

Лікування міастенічного кризу (у відділені інтенсивної терапіiі):

- припідняте положення тіла, застосування аспіратора, киснева терапія;

- внутрішньовенно піридостигмін 1-3 мл, потім постійно 0,51 мл/год через перфузатор;

- при інфекції - антибіотики (цефалоспоринового ряду);

- плазмаферез (протипоказання - сепсис, нестабільність кровообігу);

- імуноглобуліни;

- регуляція об'єму легень, контроль газового складу крові;

- при необхідності - інтубація, штучна вентиляція легень;

- імуносупресивна терапія: кортикостероїди 500-1000 мг протягом 3-5 днів + азатіоприн 50 мг із щотижневим підвищенням на 50 мг до досягнення підтримувальної дози 2-3 мг/кг маси тіла.

\section{Список рекомендованої літератури/References:}

1. Besinger U.A., Toyka K.V., Hömberg M. et al. (1983) Myasthenia gravis: long-term correlation of binding and bungarotoxin blocking antibodies against acetylcholine receptors with changes in disease severity. Neurology, 33(10): 1316-1321. doi: 10.1212/wnl.33.10.1316.

2. Gold R., Hohlfeld R., Toyka K.V. (2008) Progress in the treatment of myasthenia gravis. Ther. Adv. Neurol. Disord., 1(2): 36-51. doi: 10.1177/1756285608093888

3. Grabowski A. (2016) Emergency neurology. Clinical guidelines. Panfilov Publishing House, 592 p. (In Rus.).

\section{Відомості про авторів:}

Зозуля Іван Савович — доктор медичних наук, професор кафедри медицини невідкладних станів Національного університету охорони здоров'я України імені П.Л. Шупика, Київ, Україна. Волосовець Антон Олександрович — доктор медичних наук, доцент, завідувач кафедри медицини невідкладних станів Національного університету охорони здоров'я України імені П.Л. Шупика, Київ, Україна.

\section{Адреса для кореспонденції:}

Зозуля Іван Савович

04112, Київ, вул. Дорогожицька, 9

E-mail: nmapo.emergency@gmail.com

\section{Information about the authors:}

Zozulya Ivan S. - Doctor of Medical Sciences, Professor of the Department of Emergency Medicine of the Shupyk National Healthcare University of Ukraine, Kyiv, Ukraine.

Volosovets Anton 0. - Doctor of Medical Sciences, Associate Professor, Head of the Department of Emergency Medicine of the Shupyk National Healthcare University of Ukraine, Kyiv, Ukraine.

\section{Address for correspondence:}

Ivan Zozulya

04112, Kyiv, Dorohozhytska str., 9

E-mail: nmapo.emergency@gmail.com

Надійшла до редакції/Received: 13.06.2021 Прийнято до друку/Accepted: 02.07.2021 
ТЕСТОВІ ЗАПИТАННЯ

(один або декілька правильних варіантів відповідей на кожне запитання)

1. Який патогенез розвитку тяжкої форми міастенії?

$\square$ аутоімунний процес

$\square$ патологія вилочкової залози

$\square$ серцево-судинні захворювання

$\square$ захворювання легень

2. Яка клінічна картина тяжкої форми міастенії?

$\square$ різка м'язова слабкість

$\square$ двоїння в очах

$\square$ тахіпное, диспное, задишка

$\square$ порушення функції ковтання, мовлення

$\square$ порушення функції тазових органів

3. Класифікація міастенії включає такі форми:

$\square$ очна, око-глотково-лицьова (локальна)

$\square$ генералізована, тяжка гостра генералізована, середньої тяжкості

$\square$ тяжка хронічна прогресуюча

$\square$ міастенія з бульбарними та респіраторними порушеннями

$\square$ тяжка міастенія з трофічними вадами

4. Які провокуючі фактори розвитку міастенії?

$\square$ інфекції

$\square$ емоційний стрес

$\square$ застосування глюкокортикоїдів на початковій стадії

$\square$ цукровий діабет

5. Диференційний діагноз проводять 3:

$\square$ синдромом Гійєна — Барре

$\square$ ботулізмом

$\square$ аміотрофічним латеральним склерозом

$\square$ синдромом Ламберта - Ітона

$\square$ синдромом Туретта
6. Діагностика включає:

$\square$ серологічні реакції на антитіла

$\square$ електродіагностику

$\square$ прості клінічні тести (Сімпсона, тест з кубиком льоду, тест Когана, тест на втому повік)

$\square$ tensilon-тест

$\square$ тест товстої краплі крові

$\square$ магнітно-резонансну томографію, комп'ютерну томографію грудної клітки та середостіння

7. Лікування міастенії включає:

$\square$ контроль життєво важливих функцій

$\square$ піридостигмін (індивідуальний підбір дози)

$\square$ глюкокортикоїди

$\square$ імуноглобуліни

$\square$ спазмолітичні препарати

8. Лікування холінергічного кризу включає:

$\square$ атропін, іпратропію бромід (15 мг, максимально 180$300 \mathrm{мг/добу)}$

$\square$ піридостигмін 30 мг перорально, внутрішньовенно

$\square$ при порушенні ковтання - едрофоній

$\square$ азатіоприн 2-3 мг/кг маси тіла (2-3 рази на добу)

$\square$ серцеві глюкозиди

9. Лікування міастенічного кризу включає:

$\square$ піридостигмін внутрішньовенно 1-3 мл, потім 0,5-1 мл/год через перфузатор

$\square$ антибіотики при інфекції (цефалоспорини)

$\square$ плазмаферез (протипоказаний при сепсисі)

$\square$ імуноглобуліни

$\square$ імуносупресивна терапія (кортикостероїди протягом 3-5 днів, потім азатіоприн 50 мг, при щотижневому підвищенні дози на 50 мл до досягнення дози 2-3 мл/кг маси тіла

$\square$ теофедрин

\author{
Для отримання сертифіката дайте відповідь \\ на тестові запитання в режимі on-line \\ на сайті журналу \\ www.umj.com.ua \\ або надішліть ксерокопію сторінок \\ з відповідями разом з контактною \\ інформацією за адресою: \\ 01001, Київ-1, a/c «В»-82, ТОВ «МОРІОН»
}

\begin{tabular}{ll} 
ПІБ \\
Поштова адреса: індекс \\
область \\
район \\
місто \\
вулиця \\
будинок \\
квартира \\
\hline E-mail
\end{tabular}

